\title{
A Comparison of Existing Models for DBH Estimation from Large-scale Photos
}

\author{
by
}

\author{
R.J. Hall ${ }^{1}$, R.T. Morton ${ }^{2}$ and R.N. Nesby ${ }^{3}$
}

\begin{abstract}
The performance of 12 diameter prediction models suggested in the literature was studied in a controlled operational test. These models were linear and logarithmic transformations of tree height and/or crown area and were analyzed for white spruce, lodgepole pine, and trembling aspen and balsam poplar combined. Overall, all models were statistically significant, with differences due to variations in species and model form. Although simpler models may be adequate depending on operational objectives, two models emerged as deserving further investigation. It was unclear whether both tree height and crown area were needed as predictors of tree $\mathrm{dbh}$ for all species. Tree height was more highly correlated with dbh than crown area for all species except lodgepole pine. Measuring both tree height and crown area in comparison with tree height alone, however, increases measurement cost substantially from $\$ 10.29$ to $\$ 17.50$ per plot (1987 dollars).
\end{abstract}

\section{Résumé}

On a étudié la performance de 12 modèles de prévision du diamètre présentés dans la documentation consacrée à ce sujet en les soumettant à un essai en conditions opérationnelles contrôlées. Ces modèles consistaient en des transformations linéaires et logarithmiques de la hauteur des arbres ou de la superficie de la cime; on en a étudié l'application à l'épinette blanche, au pin tordu latifolié ainsi qu'au peuplier faux-tremble et au peuplier baumier ensemble. En général tous les modèles ont donné des résultats statistiquement significatifs; les différences observées étaient dues aux variations d'espèces et de formes de modèle. Les modèles simples peuvent donner de bons résultats, tout dépendant de l'objectif visé; dans deux cas toutefois, il y aurait lieu d'approfondir l'évaluation. II n'est pas clairement établi s'il faut nécessairement connaître la hauteur de l'arbre et la superficie de la cime pour prévoir le dhp de toutes les espèces. On a constaté que la hauteur de l'arbre est en plus forte corrélation avec le dhp que la superficie pour toutes les espèces sauf le pin tordu latifolié. Si l'on n'utilise pas seulement la hauteur de l'arbre, mais qu'on veut aussi employer la superficie de la cime, le coût des mesures monte considérablement, passant de 10,29 à 17,50\$ par parcelle (dollars de 1987).

\section{Introduction}

The ability to reliably predict individual tree diameters at breast height (dbh) from measurements of tree size on largescale photos (LSP) is an important concern in forest inventory. The use of dbh information in height-dbh curves, and diameter distributions for stand and stock tables, cover type volume tables, and single tree volume tables is fundamental to forest mensuration. With field survey data, dbh is usually a predictor of tree height. With LSP and photomensuration, this relation is

\footnotetext{
Northern Forestry Centre, Forestry Canada, 5320-122 Street, Edmonton, Alberta. T6H 355

2Silvacom Ltd., 9120-37 Avenue, Edmonton, Alberta. T6N 1 C6.
3Alberta Forestry, Lands and Wildlife, 9945-108 Street, Edmonton, Alberta. T5K $2 \mathrm{Cg}$

${ }^{4}$ Either crown width or crown area have been used as independent variables in estimating tree $\mathrm{dbh}$. Results from either have similar interpretations. Crown width estimates tend to be conservative compared with ground measurements, however, and exhibit greater variability than tree crown area measurements (Aldred and Sayn-Wittgenstein 1972). Only tree crown area was considered in this study since it is a more consistent and frequently used variable than crown width in tree dbh estimation.

${ }^{5}$ Crown area is defined as the area occupied by the projection of a tree crown onto a ground horizontal plane (Aldred and Sayn-Wittgenstein 1972).
}

reversed so that tree height is a predictor of tree $\mathrm{dbh}$. Although the question of estimating dbh from LSP measurements of total tree height and crown width 4 or crown area 5 has received some attention in the literature (Aldred and Sayn-Wittgenstein 1972; Kirby and van Eck 1977; Aldred and Lowe 1978; Jano 1978; Nielsen et al. 1979; Mervart 1984; Hagan and Smith 1986), it was evident that the relationship between these variables is not simple, nor obvious. The difficult selection of appropriate model forms for the prediction of $\mathrm{dbh}$ was therefore addressed by comparing the relative performance of existing published models, to answer the following questions:

1. What is the relationship between tree height, crown area, and $\mathrm{dbh}$ ?

2. What existing, published mathematical model(s), using height and/or crown area as predictors, is best for the prediction of $\mathrm{dbh}$ ?

\section{Methods \\ Study Area}

The study area was located $30 \mathrm{~km}$ northwest of Whitecourt, Alberta, on National Topographic System map 


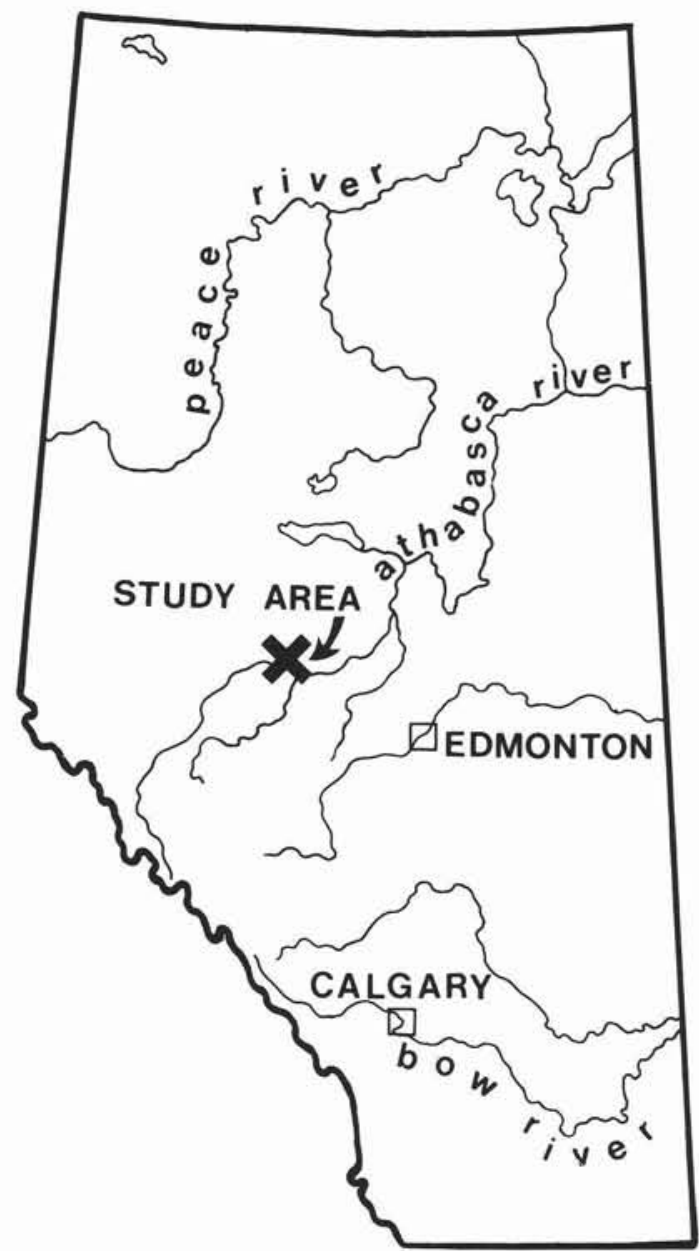

Figure 1. The study area.

sheet 83J (Figure 1) within the Mixedwood Boreal Forest Region B.18a (Rowe 1972). The area consisted of a narrow corridor approximately $1.6 \mathrm{~km}$ in length that traversed a variety of cover types exhibiting a considerable diversity in species composition, typical of the boreal forest. The species in the study area included white spruce (Picea glauca [Moench] Voss), lodgepole pine (Pinus contorta Dougl. var. latifolia Engelm.), trembling aspen (Populus tremuloides Michx.) and balsam popular (Populus balsamifera L.).

\section{Data acquisition}

Large-scale photographs were acquired in October, 1985, following leaf-off, using Kodak Double-X Aerographic 2405 film at a nominal scale of 1:1 000. Measurement photos were taken with a Vinten 6492 camera and calibrated Ernst Leitz 152 mm lens. The aircraft speed was varied according to flying conditions to ensure that the photogrammetric parameters of overlap ( $70 \%$ nominal), camera cycling, and image motion (not greater than 25 micrometers) across all photos were as equal as possible. Focusing shims were used to maintain sharp focus. Contact prints were used for photo

\footnotetext{
${ }_{6}^{6}$ Trade names are mentioned for information only and do not apply endorsement by the authors.

7 lbid.

${ }_{8} \mathrm{An}$ alternative identical model $\mathrm{DBH}=\mathrm{a}+\mathrm{bH} \log (\mathrm{CA}) 0.5$ was presented by Jano
} (1978) since $\log x=2 \log (x) 0.5$ interpretation, and a calibrated flying height for each stereopair was calculated (Kirby and Hall 1980).

Fourteen plots covering a variety of tree species and stand densities were selected along the photo flight line. Plot size was approximately $100 \mathrm{~m}^{2}$. Height and $\mathrm{dbh}$ for all trees in each plot were measured on the photos and in the field. Photo measurements were performed using a Zeiss G-2 Stereocord and a Hewlett Packard 9825 microcomputer with Dendron Resource Survey LSP compilation software ${ }^{7}$. The tree species sampled for analysis included white spruce, lodgepole pine, and deciduous (trembling aspen and balsam poplar combined).

\section{Data analysis}

A paired T-test was employed to determine whether tree heights derived from the aerial photos were significantly different from field measurements. Scattergrams and Pearson's product-moment correlations followed to examine the relationships between photo estimates of tree height and $\mathrm{dbh}$, and photo estimates of crown area and $\mathrm{dbh}$.

Fit statistics for dbh regression models included the adjusted $R^{2}$ (Verbyla 1986), standard error of the estimate, significance levels of coefficients, and estimates of bias (Ek 1973) to describe the performance of each regression model. The prediction biases were tabulated for the four smallest and largest trees, and for the four trees closest to mean diameter. T-tests were performed to assess the contribution of the regression estimators for tree $d b h$ at $p<=0.05$. Several statistics were therefore used to compare the relative performance of the regression models.

\section{Regression models analyzed}

A variety of regression models have been published for estimating tree dbh from photo measures of tree height and/ or crown area (Table 1). These models are either linear, quadratic, or logarithmic transformations of the predictor variables. Models 1 and 2 were simple linear regressions of tree height and crown area, and model 3 was a multiple linear regression. Models 4, 5, 6 and $7^{8}$ were simple linear models with tree height and crown area combined as a single predictor variable.

Models 8 and 9 were polynomial regressions utilizing various transformations of tree height as the predictor variables. Models 10, 11, and 12 were logarithmic transformations of tree height and/or crown area to estimate tree $\mathrm{dbh}$. The $\mathrm{R}^{2}$ for Model 9 was not directly comparable to $\mathrm{R}^{2}$ values from regression models that have an intercept coefficient and was therefore estimated from the ratio of regression and total sum of squares (SS). Similarly, the $R^{2}$ and standard error of estimates for models 4,10 , and 11 were calculated from untransformed predicted values. For models 10 and 11 , the logarithmic transformation uses the geometric mean rather than the arithmetic mean. The standard error of estimate was therefore calculated from the untransformed residual mean squares. A more precise estimate of the standard error can be achieved by employing the correction for logarithmic bias recommended by Baskerville (1972).

\section{Impact of measuring crown area}

There is controversy on whether both tree height and crown area are needed as predictors of $\mathrm{dbh}$. Tree height is more convenient and economical to measure on LSP than 
Table 1. Models for dbh estimation using total tree height and/or crown area.

\begin{tabular}{|c|c|c|c|}
\hline Equation & & Regression model ${ }^{1}$ & Source (if applicable) \\
\hline 1. & & $\mathrm{DBH}=\mathrm{a}+\mathrm{bH}$ & \\
\hline 2. & & $\mathrm{DBH}=\mathrm{a}+\mathrm{bCA}$ & \\
\hline 3. & & $\mathrm{DBH}=\mathrm{a}+\mathrm{bH}+\mathrm{cCA}$ & \\
\hline 4. & & $\mathrm{DBH}^{2}=\mathrm{a}+\mathrm{bHCA}$ & Aldred and Kippen 1967 \\
\hline 5. & & $\mathrm{DBH}=\mathrm{a}+\mathrm{bH}(\mathrm{CA})^{0.5}$ & $\begin{array}{l}\text { Aldred and Sayn-Wittgenstein } 1972 \\
\text { Jano } 1980 \\
\text { Mervart } 1984\end{array}$ \\
\hline 6. & & $\mathrm{DBH}=\mathrm{a}+\mathrm{bH} \log \mathrm{CA}$ & $\begin{array}{l}\text { Aldred and Sayn-Wittgenstein } 1972 \\
\text { Jano } 1980\end{array}$ \\
\hline 7. & & $\mathrm{DBH}=\mathrm{a}+\mathrm{bH}+\mathrm{cH}(\mathrm{CA})^{0.5+d(C A)^{0.5}}$ & $\begin{array}{l}\text { Aldred and Sayn-Wittgenstein } 1972 \\
\text { Kirby and van Eck } 1977\end{array}$ \\
\hline 8. & & $\mathrm{DBH}=\mathrm{a}+\mathrm{bH}+\mathrm{cH}^{2}$ & Kirby and van Eck 1977 \\
\hline 9. & & $\mathrm{DBH}=\mathrm{aH}+\mathrm{bH}^{2}+\mathrm{c}(\sin \mathrm{H}) \mathrm{H}$ & Aldred and Lowe 1978 \\
\hline 10. & & $\begin{array}{l}\mathrm{DBH}=\mathrm{aH}^{\mathrm{b}} \mathrm{CA}^{\mathrm{c}} \text { or } \\
\log \mathrm{BBH}=\log \mathrm{a}+\mathrm{blog} \mathrm{H}+\operatorname{clog} \mathrm{CA}\end{array}$ & Nielsen et al. 1979 \\
\hline 11. & & $\begin{array}{l}\mathrm{DBH}=\mathrm{aH}^{\mathrm{b}} \text { or } \\
\operatorname{logDBH}=\operatorname{loga}+\mathrm{blog} H\end{array}$ & Cited in Spencer 1984 \\
\hline 12. & & $\mathrm{DBH}=\mathrm{a}+\mathrm{b} \ln \mathrm{CA}$ & Hagan and Smith 1986 \\
\hline $\begin{array}{l}\mathrm{DBH}: \\
\mathrm{H} \text { : } \\
\mathrm{CA}: \\
\text { a,b,c,d: } \\
\text { log: } \\
\text { In: }\end{array}$ & $\begin{array}{l}\text { diameter at breast height } \\
\text { photo-measured tree height } \\
\text { photo-measured crown area } \\
\text { regression coefficients } \\
\text { log to base } 10 \\
\text { natural log }\end{array}$ & & \\
\hline
\end{tabular}

crown area. Reduced error in estimating dbh from crown area must therefore be substantial enough to warrant its use in production inventory programs.

To assess the impact of measuring crown area on operational cost, 21 random LSP forest inventory plots from Alberta Forestry, Lands and Wildlife were interpreted and measured. The time to measure each plot with and without crown area was recorded. Learning bias was minimized by ensuring that the interpreters did not view results or have access to field data prior to interpretation.

\section{Results and Discussion}

Aerial photographs were acquired on October 4, 1985, and were judged usable and representative of operational photos. On both photos and the ground, 154 trees were measured. Although there was some variation in the number of trees sampled for each species, a representative range and distribution was attained (Table 2$)^{9}$. White spruce trees

9The distribution of diameters included in this study was dictated by conditions encountered in the forest stands. exhibited the greatest variability in both diameter and height (Table 2).

For all tree species, photo estimates of tree height were not significantly different from felled measurements (Table 3 ). The height of aspen and balsam poplar trees were, however, an average of $0.67 \mathrm{~m}$ higher than ground values (Table 3 ). Field work was conducted in November, and difficulty in measuring true tree lengths of trees with broken tops were encountered due to tree felling in sub-zero temperatures $(-20$ degrees C). Lodgepole pine trees were measured and had the smallest mean difference between photo and ground measurements. Photo measures were concluded to be an acceptable estimate of actual tree heights, and standard deviations were commensurate with other published results (Titus and Morgan 1985).

\section{Correlation tests and scattergrams}

Ground-felled and photo-measured tree heights were significantly correlated with tree dbh for all species (Table 4). The lowest correlation coefficient was with the ground-felled tree height of aspen and balsam poplar (0.585) compared with photo tree height $(0.831)$; this was attributable to the broken tops during tree felling. Tree height was more highly correlated

\begin{tabular}{|c|c|c|c|c|c|c|}
\hline Tree species & $\mathrm{N}$ & Mean & Range & $\begin{array}{l}\text { Standard } \\
\text { deviation }\end{array}$ & $\begin{array}{l}\text { Standard error } \\
\text { of the mean }\end{array}$ & $\begin{array}{l}\text { Coefficient of } \\
\text { variation (\%) }\end{array}$ \\
\hline $\begin{array}{l}\text { White spruce } \\
\text { Ground felled } \mathrm{ht}(\mathrm{m}) \\
\text { Photo measured } \mathrm{ht}(\mathrm{m}) \\
\text { Ground measured } \mathrm{dbh}(\mathrm{cm})\end{array}$ & 58 & $\begin{array}{l}14.181 \\
13.655 \\
16.609\end{array}$ & $\begin{array}{l}3.2-26.7 \\
3.2-25.5 \\
3.0-41.5\end{array}$ & $\begin{array}{l}6.089 \\
5.641 \\
8.832\end{array}$ & $\begin{array}{l}0.800 \\
0.741 \\
1.16\end{array}$ & $\begin{array}{l}42.9 \\
41.3 \\
53.2\end{array}$ \\
\hline $\begin{array}{l}\text { Lodgepole pine } \\
\text { Ground felled } \mathrm{ht}(\mathrm{m}) \\
\text { Photo measured } \mathrm{ht}(\mathrm{m}) \\
\text { Ground measured } \mathrm{dbh}(\mathrm{cm})\end{array}$ & 38 & $\begin{array}{l}17.884 \\
18.003 \\
19.382\end{array}$ & $\begin{array}{r}6.2-23.5 \\
9.9-22.9 \\
12.0-35.3\end{array}$ & $\begin{array}{l}3.904 \\
3.473 \\
4.872\end{array}$ & $\begin{array}{l}0.633 \\
0.563 \\
0.79\end{array}$ & $\begin{array}{l}21.8 \\
19.3 \\
25.1 \\
\end{array}$ \\
\hline $\begin{array}{l}\text { Aspen and balsam poplar } \\
\text { Ground felled ht }(\mathrm{m}) \\
\text { Photo measured } \mathrm{ht}(\mathrm{m}) \\
\text { Ground measured } \mathrm{dbh}(\mathrm{cm})\end{array}$ & 58 & $\begin{array}{l}17.317 \\
17.983 \\
18.250\end{array}$ & $\begin{array}{l}8.3-26.0 \\
9.7-26.2 \\
7.0-31.0\end{array}$ & $\begin{array}{l}4.706 \\
3.939 \\
7.043\end{array}$ & $\begin{array}{l}0.618 \\
0.517 \\
0.92\end{array}$ & $\begin{array}{l}27.2 \\
21.9 \\
38.6\end{array}$ \\
\hline
\end{tabular}


Table 3. Paired T-test results by species for ground felled vs photo-measured tree heights

\begin{tabular}{lcccccc}
\hline Tree species & $\mathrm{N}$ & $\begin{array}{c}\text { Correlation } \\
\text { coefficient }\end{array}$ & $\begin{array}{c}\text { Mean } \\
\text { difference }(\mathrm{m})\end{array}$ & $\begin{array}{c}\text { Standard } \\
\text { deviation }(\mathrm{m})\end{array}$ & $\begin{array}{c}\text { Calculated } \\
\text { T-value }\end{array}$ & $\begin{array}{c}\text { Probability } \\
\text { level' }(2 \text {-tail) }\end{array}$ \\
\hline White spruce & 58 & 0.914 & 0.526 & 2.477 & 1.62 & 0.111 \\
Lodgepole pine & 38 & 0.716 & -0.118 & 2.808 & -0.26 & 0.796 \\
Aspen and balsam poplar & 58 & 0.571 & -0.666 & 4.062 & -1.25 & 0.217 \\
\hline
\end{tabular}

'Neither of these values was statistically significant at the $5 \%$ probability level.

with tree dbh than crown area for all species except lodgepole pine (Table 4), for which crown area was more important. This may be a characteristic of the species or an artifact of the sample. A larger sample would be needed to verify the consistency of this association.

Tree heights versus $\mathrm{dbh}$ for lodgepole pine exhibited less of a linear association than for other species (Figure 2). There was, however, a definite curvilinear pattern with crown area (Figure 3). White spruce crown areas were the most variable (Figure 3). Scattergrams of tree height and crown area with $\mathrm{dbh}$ for aspen and balsam poplar combined, exhibited a curvilinear pattern that was more definitive for crown area (Figure 2) than from tree height (Figure 3 ).

\section{Regression results}

Regression statistics for each model (Table 1) have been summarized by species in Tables 5,6 , and 7 . All regression models were statistically significant, with no one model producing a substantially smaller standard error of estimate than any other. The higher the correlation with tree $\mathrm{dbh}$, the higher the accuracy of the simple linear models 1 and 2 (Table 1). Regression models with higher polynomial terms (e.g., models $7,8,9$; Tables 5-7) generally produced regression coefficients that were not statistically significant at $p<0.05$. This result suggests simpler models may be adequate, but further investigation is warranted before use.

Across all species groups, models $3,7,9$, and 10 ranked consistently within the top five of all models, based on adjusted $\mathrm{R}^{2}$ and standard error values (Tables 5-7). There was no further pattern as to the ranking of regression models across all species. The highest adjusted $R^{2}$ values were not associated with the lowest standard error of the estimates. This result was due to the varying correlations of the predictor variables with $\mathrm{dbh}$, the different model forms in accounting for the variation in $\mathrm{dbh}$ estimation, and the effects of multicollinearity. Multicollinearity was especially evident in models 7 and 9 and was exemplified by the lack of significance of some of the predictor variables. This often occurs when predictor variables are merely transformations of each other. The effect of multicollinearity was also reflected in the prediction biases across the range of data. Especially for Model 9, a large prediction bias for the large or small trees was evident (Table 8 ). None of the four models were

Table 4. Correlation coefficients for tree height and crown area with ground-measured tree $\mathrm{dbh}$ by species

\begin{tabular}{lccc}
\hline & \multicolumn{3}{c}{ Correlation coefficients } \\
\cline { 2 - 4 } & $\begin{array}{c}\text { Ground } \\
\text { felled } \\
\text { Tree } \\
\text { height }\end{array}$ & $\begin{array}{c}\text { Photo } \\
\text { measured } \\
\text { Tree } \\
\text { height }\end{array}$ & $\begin{array}{c}\text { Photo } \\
\text { measured } \\
\text { Crown } \\
\text { area }\end{array}$ \\
\hline Tree Species & $0.961^{\circ}$ & $0.874^{\circ}$ & $0.720^{\circ}$ \\
\hline $\begin{array}{l}\text { White spruce tree dbh } \\
\text { Lodge pole pine tree dbh }\end{array}$ & $0.501^{\circ}$ & $0.413^{\circ}$ & $0.788^{\circ}$ \\
Aspen and balsam poplar & $0.585^{\circ}$ & $0.831^{\circ}$ & $0.817^{\circ}$ \\
tree dbh & & & \\
\hline
\end{tabular}

Highly significant at the $5 \%$ probability level $(<0.005)$. consistent in the magnitude or direction (over-or underestimate) of prediction biases over the entire data range. In general, Model 3 prediction bias was closest to zero when
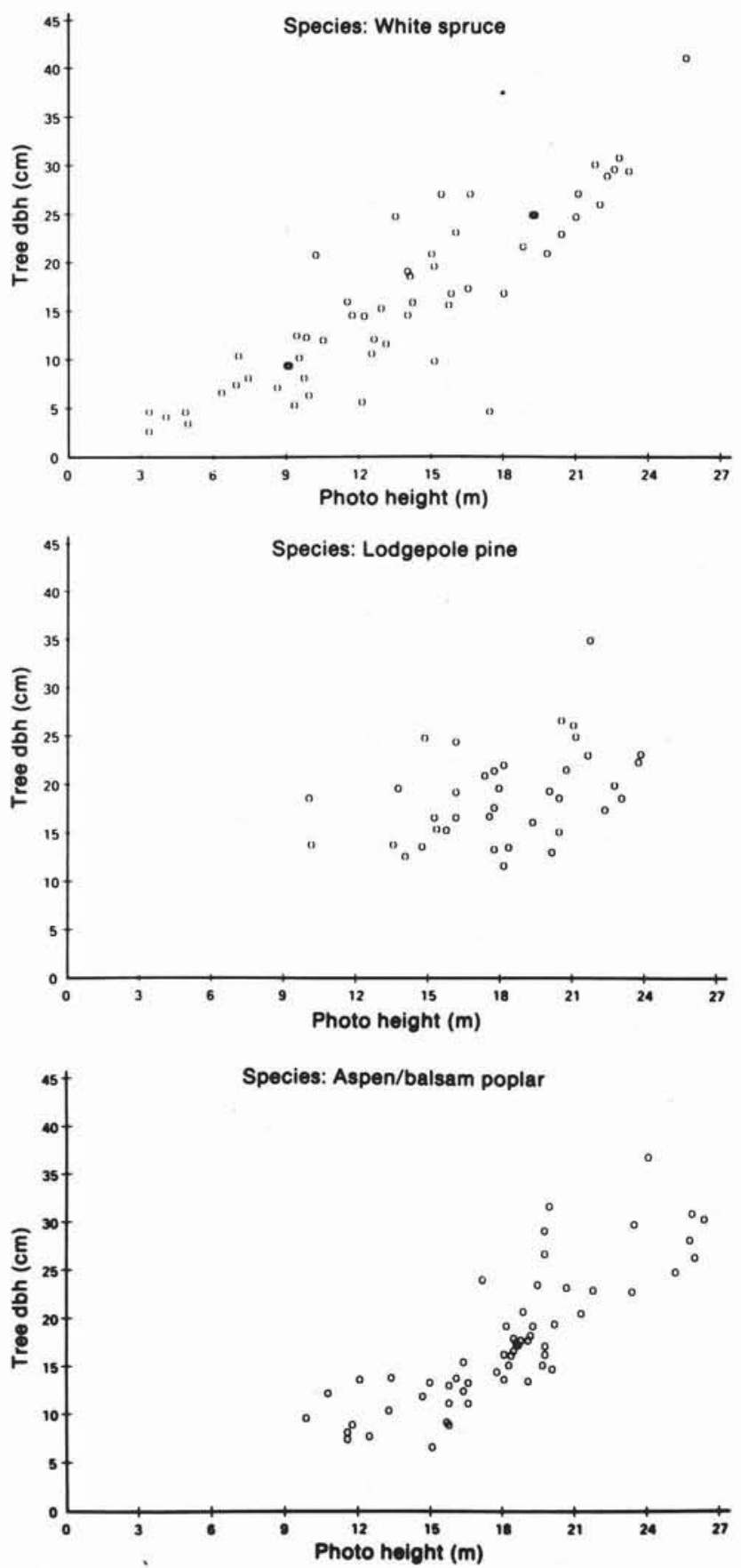

Figure 2. Scattergrams of tree $\mathrm{dbh}$ and photo-measured tree heights. 


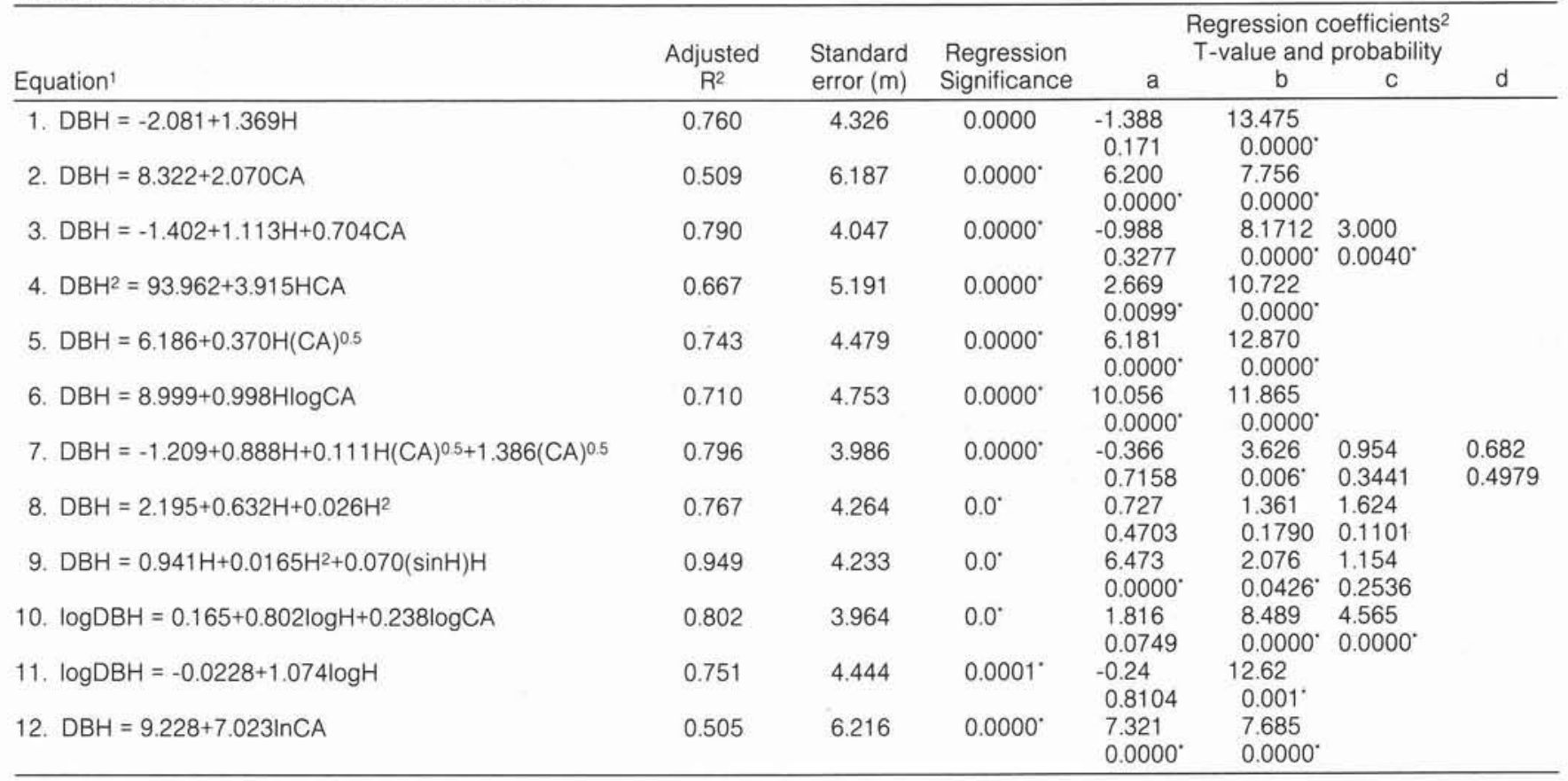

Ivariable letters identified in Table 1, footnote 1

2letters refer to model coefficients in Table 1

'statistically significant at $5 \%$ probability leve

all species were considered. Based on the four models selected, models 3 and 10 were selected as potential models deserving further investigation. Based on the limited data set utilized, it was not possible to recommend a single regression model for all species that would perform statistically "better" than any other. These models may therefore be considered as a basis for consideration when developing operational equations.

\section{Impact of measuring crown area}

Alberta Forestry, Lands and Wildlife budgets $\$ 17.50$ per plot for LSP inventory operations, and both tree height and

\section{Table 6. Regression statistics for lodgepole pine}

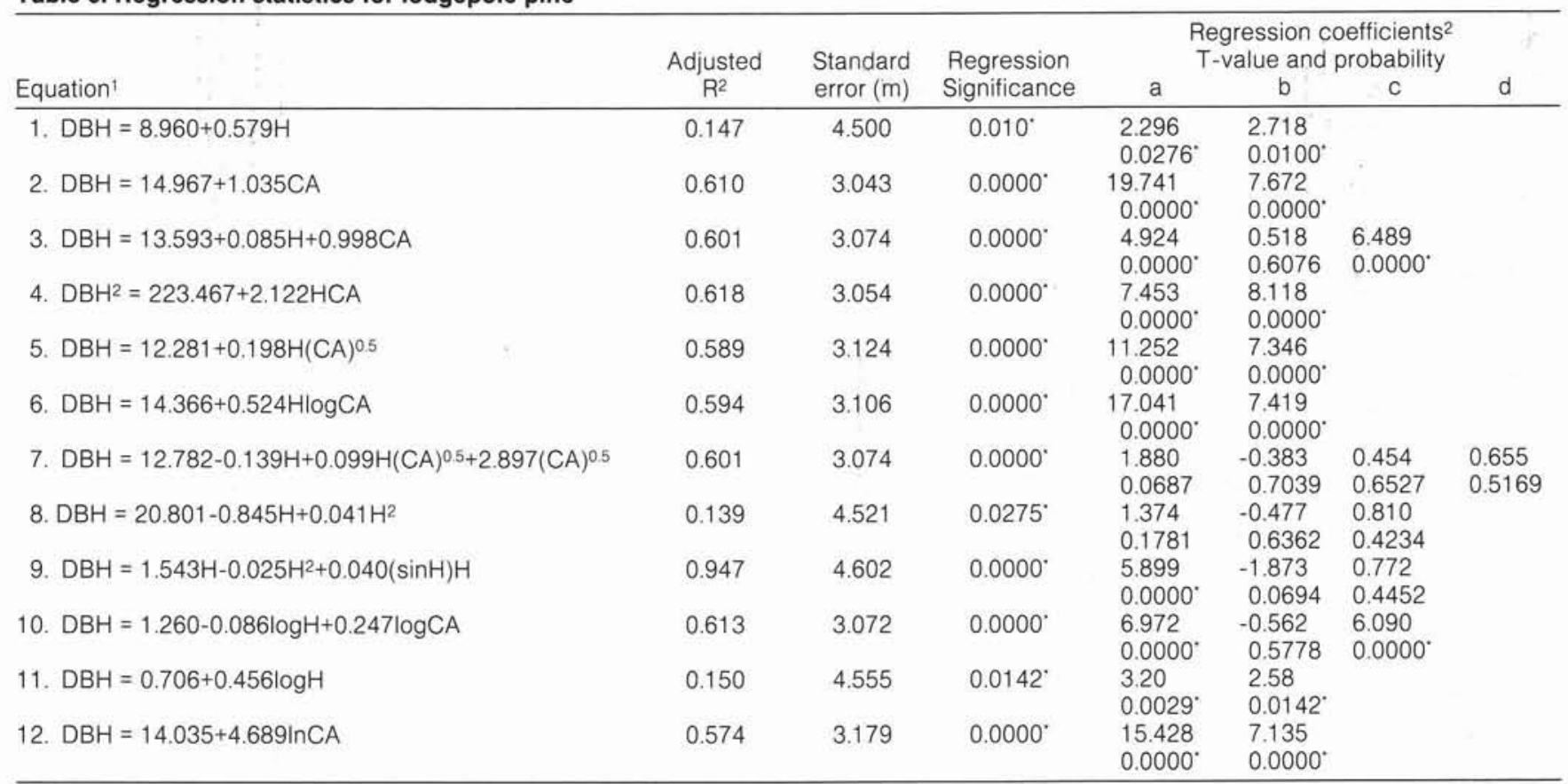

'variable letters identified in Table 1, footnote 1

letters refer to model coefficients in Table 1

statistically significant at $5 \%$ probability leve. 


\begin{tabular}{|c|c|c|c|c|c|c|c|}
\hline \multirow[b]{2}{*}{ Equation ${ }^{1}$} & \multirow{2}{*}{$\begin{array}{l}\text { Adjusted } \\
\mathrm{R}^{2}\end{array}$} & \multirow{2}{*}{$\begin{array}{l}\text { Standard } \\
\text { error }(m)\end{array}$} & \multirow{2}{*}{$\begin{array}{l}\text { Regression } \\
\text { Significance }\end{array}$} & \multicolumn{4}{|c|}{$\begin{array}{l}\text { Regression coefficients }{ }^{2} \\
T \text {-value and probability }\end{array}$} \\
\hline & & & & a & b & C & $d$ \\
\hline 1. $\mathrm{DBH}=-8.457+1.485 \mathrm{H}$ & 0.684 & 3.956 & $0.0000^{\circ}$ & $\begin{array}{l}-3.455 \\
0.0011\end{array}$ & $\begin{array}{c}11.164 \\
0.0000^{\circ}\end{array}$ & & \\
\hline 2. $\mathrm{DBH}=11.263+1.410 \mathrm{CA}$ & 0.662 & 4.096 & $0.0000^{\circ}$ & $\begin{array}{c}13.245 \\
0.0000^{\circ}\end{array}$ & $\begin{array}{c}10.609 \\
0.0000^{\circ}\end{array}$ & & \\
\hline 3. $\mathrm{DBH}=-3.782+0.979 \mathrm{H}+0.893 \mathrm{CA}$ & 0.873 & 2.505 & $0.0^{\circ}$ & $\begin{array}{l}-2.319 \\
0.0242\end{array}$ & $\begin{array}{l}9.731 \\
0.0000^{\circ}\end{array}$ & $\begin{array}{l}9.202 \\
0.0000^{\circ}\end{array}$ & \\
\hline 4. $\mathrm{DBH}^{2}=104.408+2.837 \mathrm{HCA}$ & 0.760 & 3.132 & $0.0000^{\circ}$ & $\begin{array}{l}3.728 \\
0.0005^{\circ}\end{array}$ & $\begin{array}{c}13.484 \\
0.0000^{\circ}\end{array}$ & & \\
\hline 5. $\mathrm{DBH}=6.872+0.293 \mathrm{H}(\mathrm{CA})^{0.5}$ & 0.858 & 2.649 & $0.0000^{\circ}$ & $\begin{array}{l}9.778 \\
0.0000^{\circ}\end{array}$ & $\begin{array}{l}18.628 \\
0.0000^{\circ}\end{array}$ & & \\
\hline 6. $\mathrm{DBH}=10.849+0.706 \mathrm{H} \log \mathrm{CA}$ & 0.796 & 3.178 & $0.0000^{\circ}$ & $\begin{array}{c}16.766 \\
0.0000\end{array}$ & $\begin{array}{c}14.964 \\
0.0000\end{array}$ & & \\
\hline 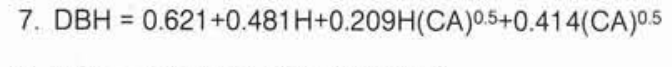 & 0.876 & 2.478 & $0.0000^{\circ}$ & $\begin{array}{l}0.140 \\
0.8888\end{array}$ & $\begin{array}{l}1.844 \\
0.0725\end{array}$ & $\begin{array}{l}1.832 \\
0.0706\end{array}$ & $\begin{array}{l}0.193 \\
0.8473\end{array}$ \\
\hline 8. $\mathrm{DBH}=3.017+0.159 \mathrm{H}+0.0365 \mathrm{H}^{2}$ & 0.691 & 3.918 & $0.0^{\circ}$ & $\begin{array}{l}0.365 \\
0.7161\end{array}$ & $\begin{array}{l}0.173 \\
0.8634\end{array}$ & $\begin{array}{l}1.454 \\
0.1517\end{array}$ & \\
\hline 9. $\mathrm{DBH}=0.471 \mathrm{H}+0.029 \mathrm{H}^{2}-0.025(\sin \mathrm{H}) \mathrm{H}$ & 0.960 & 3.910 & $0.0^{\circ}$ & $\begin{array}{l}3.110 \\
0.003^{\circ}\end{array}$ & $\begin{array}{l}3.791 \\
0.0004\end{array}$ & $\begin{array}{l}-0.573 \\
0.5689\end{array}$ & \\
\hline 10. $\mathrm{DBH}=-0.0044+0.904 \log \mathrm{H}+0.208 \log \mathrm{CA}$ & 0.868 & 2.578 & $0.0^{\circ}$ & $\begin{array}{l}-0.038 \\
0.9695\end{array}$ & $\begin{array}{l}9.322 \\
0.0000^{\circ}\end{array}$ & $\begin{array}{l}9.229 \\
0.0000^{\circ}\end{array}$ & \\
\hline 11. $\mathrm{DBH}=-0.522+1.408 \log \mathrm{H}$ & 0.691 & 3.953 & $0.0001^{*}$ & $\begin{array}{l}-3.31 \\
0.0016\end{array}$ & $\begin{array}{c}11.12 \\
0.0001 .\end{array}$ & & \\
\hline 12. $\mathrm{DBH}=11.417+5.611 \mathrm{ln} \mathrm{CA}$ & 0.616 & 4.364 & $0.0000^{\circ}$ & $\begin{array}{l}12.506 \\
0.0000\end{array}$ & $\begin{array}{l}9.615 \\
0.0000\end{array}$ & & \\
\hline
\end{tabular}

'variable letters identified in Table 1, footnote 1

2letters refer to model coefficients in Table 1

statistically significant at $5 \%$ probability level.

crown area are measured 10 . Without measuring crown area, the LSP production rate would increase to 17 plots per day and the cost would fall to $\$ 10.29$ per plot. Including the time to set up the stereomodel, total plot measurement time was $1.7 x$ longer for measuring both tree height and crown area than for measuring tree height alone; measuring crown area therefore increases costs substantially.

\section{Conclusions}

This study compared previous work on dbh estimation from large-scale photos. Tree height was most highly correlated with $\mathrm{dbh}$ for all species except lodgepole pine; it was the most accurately measured of all species for tree height, but crown area was more highly correlated with tree diameter. Crown area is therefore concluded to be a stronger predictor of $\mathrm{dbh}$ than tree height for lodgepole pine. Further

10Personal communications with $\mathrm{H}$. Archibald, Land Information Services Division, Alberta Forestry, Lands \& Wildlife, February 18, 1988. work over a larger area and data set is recommended to confirm this association.

Of the 13 regression models analyzed (Table 1 ), all were statistically significant, and models $3,7,9$, and 10 were the best performers across all species. Multicollinearity was evident in models 7 and 9 as was exemplified by the low significance of some predictor variables. Particularly for Model 9, the effect of multicollinearity was also evident by large positive or negative prediction biases across the range of data.

Regression models with a greater number of terms generally produced coefficients which were not statistically significant. Simpler models may therefore deserve more attention than what the literature has exemplified. Based on the limited data set utilized, it is difficult to recommend a single best equation. Models 3 and 10 are therefore suggested for further investigation as possible $\mathrm{dbh}$ functions:

Model 3: $\mathrm{DBH}=\mathrm{a}+\mathrm{bH}+\mathrm{cCa}$

Model 10: $\mathrm{DBH}=\mathrm{aHbCAc}$

Table 8. Estimates of average diameter predication bias for the top four models.

\begin{tabular}{|c|c|c|c|c|}
\hline \multirow[b]{2}{*}{ Species } & \multirow[b]{2}{*}{$\begin{array}{l}\text { Model } \\
\text { number }\end{array}$} & \multicolumn{3}{|c|}{ Prediction bias $(\mathrm{cm})$} \\
\hline & & $\begin{array}{c}\text { Four smallest } \\
\text { trees }\end{array}$ & $\begin{array}{l}\text { Four trees closest } \\
\text { to mean diameter }\end{array}$ & $\begin{array}{c}\text { Four largest } \\
\text { trees }\end{array}$ \\
\hline White spruce & $\begin{array}{r}3 \\
7 \\
9 \\
10\end{array}$ & $\begin{array}{r}-0.048 \\
0.286 \\
-0.095 \\
0.468\end{array}$ & $\begin{array}{l}1.453 \\
1.418 \\
0.634 \\
1.023\end{array}$ & $\begin{array}{l}-2.427 \\
-2.107 \\
-2.906 \\
-2.802\end{array}$ \\
\hline Lodgepole pine & $\begin{array}{r}3 \\
7 \\
9 \\
10\end{array}$ & $\begin{array}{l}3.791 \\
3.329 \\
6.132 \\
3.101\end{array}$ & $\begin{array}{c}0.739 \\
1.225 \\
1.407 \\
1.10\end{array}$ & $\begin{array}{l}-1.473 \\
-1.982 \\
-6.516 \\
-3.216\end{array}$ \\
\hline Aspen and balsam poplar & $\begin{array}{r}3 \\
7 \\
9 \\
10\end{array}$ & $\begin{array}{l}1.388 \\
1.448 \\
2.512 \\
1.219\end{array}$ & $\begin{array}{l}2.030 \\
2.293 \\
0.957 \\
2.307\end{array}$ & $\begin{array}{r}-2.751 \\
-2.687 \\
15.259 \\
-4.258\end{array}$ \\
\hline
\end{tabular}



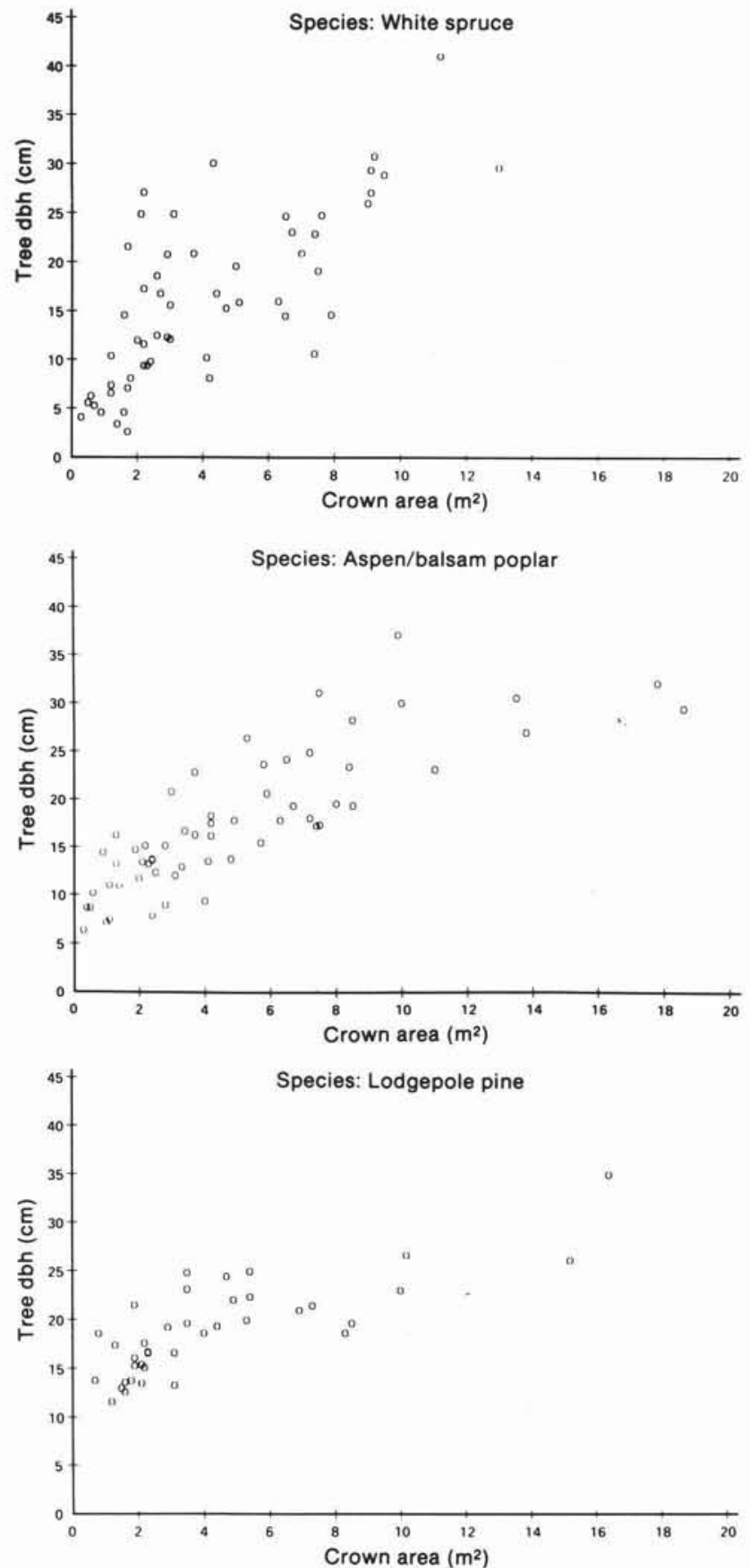

Figure 3. Scattergrams of tree dbh and photo-measured crown area.

An alternative approach to predicting $\mathrm{dbh}$ is in deriving the model form to fit the data. Is there, however, adequate biological justification for deriving different models for different species and stand conditions? Further investigation is suggested to investigate nonlinear modelling and incorporation of ecological rationalization through site and stand characteristics. New derived model performance could then be compared with that of existing models.

It is generally thought that including crown area with tree height to predict dbh results in greater accuracy at the expense of plot measurement production rate. Comparing the regression statistics for each species suggests, however, that crown area doesn't consistently result in more accurate dbh estimates. In 1987 dollars, including crown area increases the per plot measurement cost from $\$ 10.29$ to $\$ 17.50$. With increasing labour costs and the well-known difficulties of measurement consistencies between interpreters, the gains from incorporating crown area will need to be more closely monitored in future inventory surveys. Its benefits at present are not obvious.

In conclusion, a comparison of existing models has resulted in two models that hold potential for application in the Mixedwood Boreal Forest of Alberta. The recommended models for future operational LSP inventory surveys in Alberta will entail a larger database and a comparison between derived models to these recommended existing models.

\section{Acknowledgments}

This project was funded as a demonstration project by the Alberta Remote Sensing Center. The Resource Evaluation and Planning Branch (now Land Information Services Branch) of Alberta Forestry, Lands and Wildlife provided the aircraft and film processing The field assistance provided by Tom Grabowski, Dave Taylor, and Tom Walsh and technical assistance by Andre Kruger and Dean Patterson are appreciated. Helpful review comments were provided by Drs. Steve Titus (University of Alberta) and Richard Yang (CFS).

\section{References}

Aldred, A.H. and F.W. Kippen. 1967. Plot volumes from large-scale 70-mm air photographs. For. Sci. 13:419-427

Aldred, A.H. and J.J. Lowe. 1978. Application of large-scale photos to forest inventory in Alberta. Can. For. Serv., For. Manage. Inst. Ottawa, Ontario. Inf. Rep. FMR-X-40.

Aldred, A.H. and L. Sayn-Wittgenstein. 1972. Tree diameters and volumes from large-scale aerial photographs. Can. For. Serv. For. Manage. Inst. Ottawa, Ontario. Inf. Rep. FMR-X-40.

Baskerville, G.L. 1972. Use of logarithmic regression in the estimation of plant biomass. Can. J. For. Res. 2:49-53.

Ek, A.R. 1973. Performance of regression models for tree height estimation with small sample sizes. pp. 67-80 in Statistics in Forestry Research. IUFRO Subject group S6.02. Vancouver, B.C.

Hagan, G.F. and J.L. Smith. 1986. Predicting tree groundline diameter from crown measurements made on $35-\mathrm{mm}$ aerial photography. Photogramm. Eng. Remote Sensing 52:687-690.

Jano, A. 1978. Aerial cruising. Ont. Minist. Nat. Resour., Ont. Cent. Remote Sensing. Toronto, Ontario.

Jano, A. 1980. Large-scale photography for forest inventory: problems and limitations. pp. 52-57 in C.L. Kirby and R.J. Hal (compilers). Proc. practical application of remote sensing to timber inventory workshop. Environ. Can., Can. For. Serv. North. For. Res. Cent., Edmonton, Alberta. Inf. Rep. NOR-X224.

Kirby, C.L. and R.J. Hall. 1980. Description and accuracy evaluation of the Honeywell radar altimeter. Environ. Can., Can. For. Serv. North. For. Res. Cent., Edmonton, Alberta. Inf. Rep. NOR-X222.

Kirby, C.L. and P.I. van Eck. 1977. A basis for multistage forest inventory in the Boreal forest region. pp. 72-94. in Proc. 4th Canadian Symposium on Remote Sensing. May 16-18, 1977. Quebec, Que. (K.P.B. Thomson, Chairman)

Mervart, J.A. 1984. Application of "aerial cruising" on cover type basis. pp. 280-284 in Proc. Inventorying Forest and Other Vegetation of the High Latitude and High Altitude Regions. Fairbanks, Alaska. Edited by V.J. Labou and C.L. Kerr. Soc. Amer. For. Bethesda, MD.

Nielson, U., A.H. Aldred, and D.A. MacLeod. 1979. A forest inventory of the Yukon using large-scale photo sampling techniques. Can. For. Serv., For. Manage. Inst. Ottawa, Ontario FMR-X-121

Rowe, J.S. 1972. Forest regions of Canada. Environ. Can., Can. For. Serv. Ottawa, Ontario. Publ. 1300.

Spencer, R.D. and R.J. Hall. 1988. Canadian large-scale aerial photographic systems (LSP). Photogramm. Eng. Remote Sensing 54:475-482.

Titus, S.J. and D.J. Morgan. 1985. Tree height: Can large scale photo measurements be more accurate than field measurements? For. Chron. 61:214-217.

Verbyla, D. 1986. Potential prediction bias in regression and discriminant analysis. Can. J. For. Res. 16:1255-1257. 